\title{
De sønderjyske byers ældste historie
}

\author{
En topografisk - historisk studie
}

\section{Ole Harck}

I de sidste år har undersøgelser omkring de middelalderlige købstæders oprindelse hørt til den historisk-arkæologiske forsknings interessanteste opgaver. Derved er det lykkedes at skitsere nogle hovedlinier- også gældende for det sønderjyske område. Disse tydeliggøres fremfor alt ved sammenligning med de samtidige forhold i Holsten, der af denne grund inddrages i redegørelsens første del.

Den ældste by på den jyske halvø er utvivlsomt Hamborg, idet bebyggelsen på det næs, der fra naturens side er opstået ved floden Alsters sammenløb med Elben, i 831 - og dermed tidligere end nogen anden lokalitet i regionen - betegnes som civitas. ${ }^{1} 14$ år senere beretter kirkemanden Rimbert, der siden blev Ansgars efterfølger som ærkebisp i Hamborg-Bremen, i den af ham forfattede Vita Anskarii om et vikingeangreb på bispestaden ved Elben. ${ }^{2}$ Ifølge vore dages arkæologiske og topografiske undersøgelser bestod byen i 845 af et få år tidligere opført borganlæg - Hammaburg - med Ansgars missionskirke inden for den beskyttende vold, en større bosætning uden for dette forsvarsanlæg og et havneområde på halvøens sydside. ${ }^{3}$ I den latinske beretning om vikingernes hærgen kaldes Hamborg skiftevis for civitas eller urbs, den ubeskyttede del af byen for suburbium. Over for dette bruges betegnelsen vicus i forbindelse med oplandets bondelandsbyer, der blev plyndret ved samme lejlighed. ${ }^{4}$

Der er flere grunde til, at Hamborg inddrages i denne sammenhæng: Byens historie i 800-tallets første halvdel er godt belyst, i hvert fald sammenlignet med anden samtidig bebyggelse så langt mod nord. Den skriftlige dokumentation indeholder adskillige oplysninger om det lille bysamfund ved Jyllands fod, der bidrager til viden om den politiske, kirkelige og materielle situation $\mathrm{i}$ årene fra ca. 830-845. Dernæst bør det betænkes, at Hamborgs ødelæggelse i 845 fik til følge, at bispesædet herefter blev flyttet til det mere sikre Bremen ved Weseren, hvorved Nordeuropas åbning for sydlig indflydelse i mange henseender forsin- 
kedes betydeligt. ${ }^{5}$ Dette forhold medførte muligvis, at udbredt bymæssig bebyggelse efter centraleuropæisk mønster først fik indpas i Norden senere end f.eks. i Nordtyskland. ${ }^{6}$ Endelig er det $i$ forbindelse med genopbygningen efter krigen lykkedes for tyske arkæologer under ledelse af $\mathrm{R}$. Schindler at fremdrage spor af den aldste by gemt dybt under den $\mathrm{i}$ anden verdenskrig sønderbombede storstads ruindynger. ${ }^{7}$

Udgravningsvirksomheden gav ikke alene indblik i fortidens topografiske situation og materielle kulturs velsignelser, men også en chance for at kontrollere den historiske overlevering og supplere denne, f.eks. ved lokaliseringen af bysamfundets institutioner dateret til tiden op mod år 845 (fig. 1a), det efterfølgende sene 9. og 10. århundrede og middelalderens dage fra år 1000 frem til 1200 (fig. 1b). ${ }^{8}$ Fra perioden efter vikingernes overfald kendes udelukkende rester af en udbredt bosætning på næsset, dog ingen markante bygningsværker, der kan have tilhørt en verdslig eller kirkelig institution. Over for dette viser
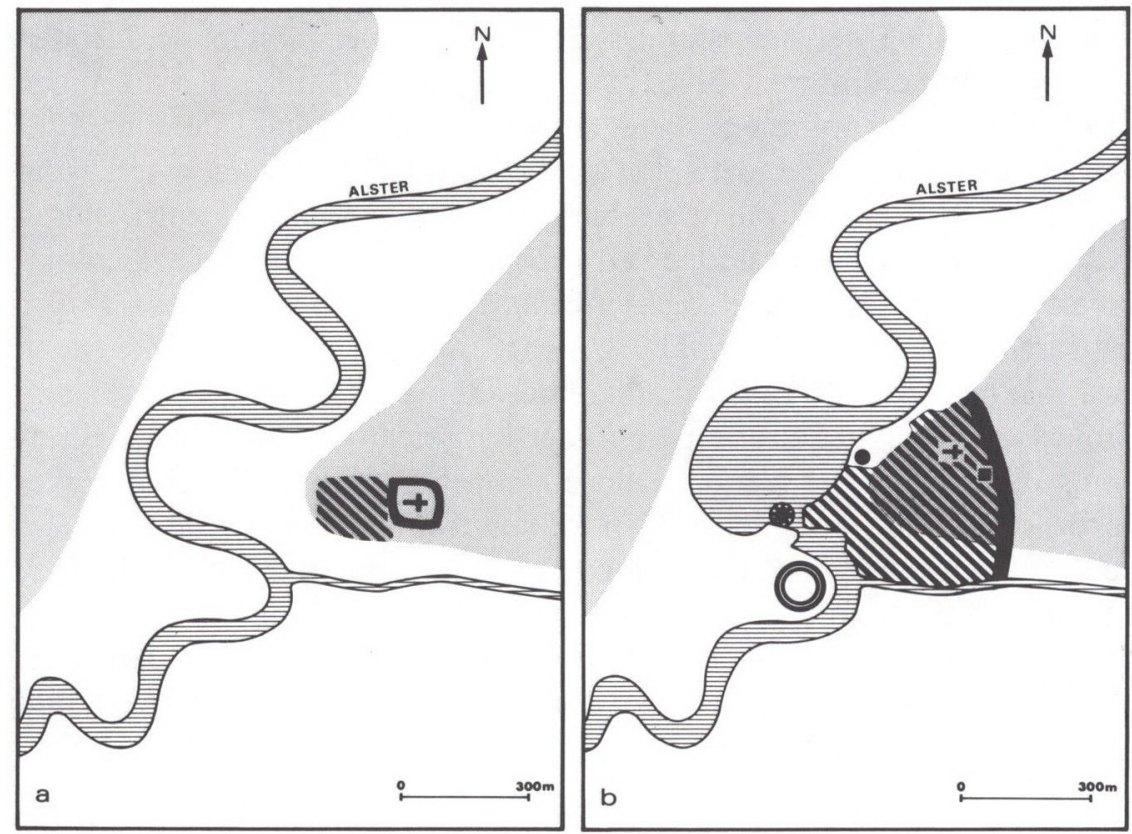

Fig. 1. a. Hamborg omkring 845. Borgvold med missionskirke og udenomliggende suburbium (skraveret); b. Hamborg $i$ det 11-12. århundrede. Tvarvold, bebygget område (skraveret), domkirke, bispeto̊rn (kvadratisk signatur), statholderbolig (rund signatur), vandmolle ved den opdammede Alster og hertugelig borg hinsides floden. Grundmorane gråfarvet. Omtegnet efter $R$. Schindler og D. Bohnsack. 
middelalderens byplan både en beskyttende vold på tværs af næsset, kirker - blandt andet en domkirke liggende på ruinerne af Ansgars missionskirke -, faste stenhuse til statholder og bisp i hver sit hjørne af byen, en vandmølle ved den opdæmmede Alster og endelig - i 1061 - en hertugelig borgvold vest for byområdet hinsides Alsterens nedre løb. ${ }^{9}$

I Hamborg kan der såvel fra arkæologisk som fra historisk side påvises en bosætningskontinuitet siden 800 -tallets dage og derudover dokumenteres et markant skift $i$ bebyggelsesstrukturen af betydning for den følgende analyse: Den ældste stad karakteriseredes af en ringborg med kirkebygning og et ubeskyttet suburbium. Århundreder senere lå kirkerne spredt rundt omkring $\mathrm{i}$ byen, hvor menigheden holdt til. Byarealet beskyttedes i middelalderen af en langstrakt jordvold på tværs af næsset, mens hertugernes statholder opholdt sig enten $i$ et stenhus blandt byens indbyggere eller på et velbeskyttet borganlæg, adskilt fra byområdet ved et bredt vandløb.

Afvigelserne mellem 800-tallets og middelalderens byplan skyldes ikke alene en tidsmæssig forskel på ca. 300 år, men genspejler i lige så høj grad en samfundsmæssig udvikling. Dette fremgår blandt andet af en sammenligning med den topografiske situation omkring lokaliteten Gammel Lybæk ca. $70 \mathrm{~km}$ nordøst for Hamborg. Her svarede socialstrukturen og den topografiske situation i 1100-tallets dage, altså ca. 250 år efter Ansgartidens Hamborg, nærmest til de ovenomtalte aldste forhold ved Alsterens munding. ${ }^{10}$ Ved sammenløbet mellem det lille vandløb Schwartau og den større, delvis sejlbare flod Trave, der udspringer $\mathrm{i}$ den østholstenske ungmoræne nær Segeberg, er der i tidens løb opstået et langstrakt næs, hvis ca. $200 \mathrm{~m}$ brede, strategisk vigtige spids fremhæves af en betydelig ringvold, Gammel Lybæk (fig. 2). Nyere udgravninger ledsaget af moderne naturvidenskabelige dateringsmetoder har kunnet påvise en ældre slavisk borgvold fra tiden mellem 810 og 820 , som siden blev udbygget i Obodritfyrsten Godskalks regeringstid (1043-1066) og fik sin endelige form under sønnen Henriks styre (1093-1127). Sidstnævnte opførte den i voldanlæggets centrum liggende stenkirke som fyrsteligt hof- og begravelseskapel. Herfra påbegyndte Neumünster-munken Vicelin i 1126 en udbredt missionsvirksomhed.

Mens de inden for borgen liggende bygninger enten tjente til boligformål for regenten, hans familie og en hird eller også fandt anvendelse som møntsted, værksteder og forrådshuse, har udgravninger i området udenfor kunnet sandsynliggøre et større suburbium med bygninger, der bl.a. brugtes til udøvelse af forskellige håndværk. 


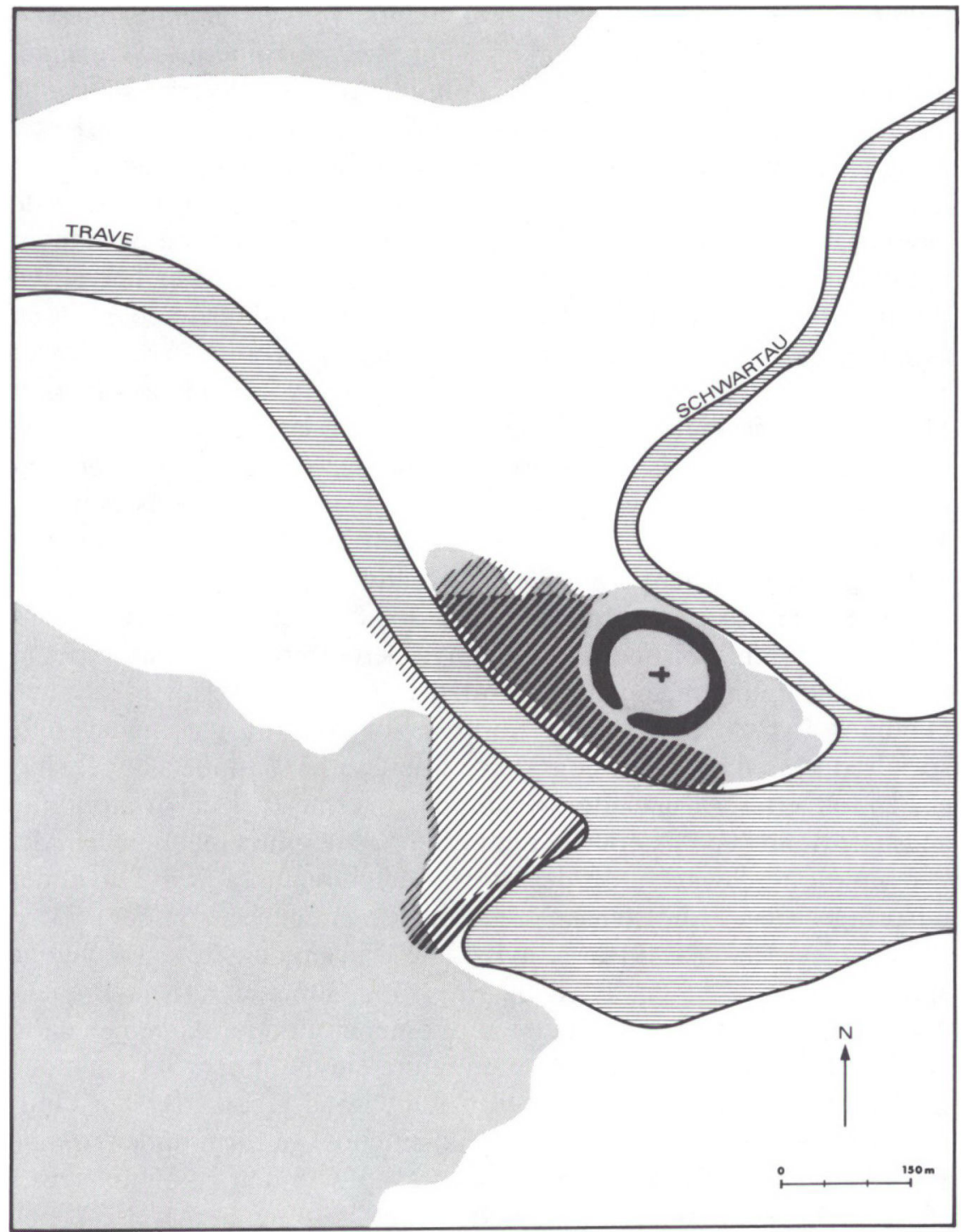

Fig. 2. Gammel Lybak. Ringvold med missionskirke fra 1100-tallet. Udenom suburbium (skraveret) og kabmandsbebyggelse $p d$ den modsatte flodbred. Omtegnet efter $W$. Neugebauer. Grundmorane grdfarvet. 
Hinsides Traven er der derimod fremdraget spor af et havneanlæg og huse, der antagelig stammer fra en købmandsbebyggelse. Det formodes endvidere, at der her også har ligget en kirke.

Gammel Lybæk viser - trods tidsforskellen på 250 år - en topografisk situation, som stort set svarer til Hamborgs før 845 . Overensstemmende er en velbefæstet ringvold, der beskyttede regentens eller statholderens residens og derudover rummede en missionskirke, og det udenfor liggende suburbium med et håndværks- og købmandskvarter, hvis opbygning begge steder ikke er undersøgt i enkeltheder endnu. Over for denne bosætning, hvis fælles struktur godt kan være fremkommet ved tilfældigheder uafhængigt af hinanden, bør det nævnes, at der ved flere saksiske voldsteder i Vestholsten og Ditmarsken ikke kendes spor af suburbier eller en historisk overleveret funktion som residenssted af lokal eller regional betydning. ${ }^{11}$ Tilsvarende kan nævnes for et større antal slaviske ringvolde $\mathrm{i}$ Østholsten fra tiden mellem $800 \mathrm{og}$ $1150 .{ }^{12}$ Disse anlæg karakteriseres ligefrem af en mangel på bymæssig struktur uden om voldene. Dette gælder også for den vigtige lokalitet Oldenburg, det slaviske Starigard, hvor der ved omfattende undersøgelser inden for det mægtige voldsted siden 1973 er fremdraget mange arkæologiske beviser for den i de historiske kilder næunte lokaladel og rester af avanceret håndværkskunst i senslavisk tid, men åbenbart ingen spor af det handelscentrum (civitas) og torv (forum), som de skriftlige kilder nævner omkring $1150 .{ }^{13} \mathrm{I}$ anden halvdel af 900 -tallet oprettedes et første bispedømme inden for det vestslaviske område $i$ Oldenburg. Det grundlagdes påny - efter en vakance siden 1066 - i 1150, men flyttedes så 10 år senere til den nyoprettede by Lybæk et par kilometer sydvest for det ældre ovenomtalte voldsted af samme navn. Det er uvist, om bispen i Oldenburg overhovedet har kunnet tage ophold inden for eller uden for volden i bispedømmets første periode, idet Østholsten i lang tid var præget af en stærk hedensk reaktion, der forst blev knust $i$ anden halvdel af 1100-tallet. Hvis der i tilknytning til det mægtige voldsted har eksisteret et suburbium, så kan dette kun have haft samme betydning som i Hamborg og Gammel Lybæk. Oldenburg ville dermed høre til gruppen af primære handelspladser med en direkte politisk, juridisk og økonomisk afhængighed af magtcentret inden for volden.

Konklusionen af denne korte oversigt må være den, at de ældste bymæssige bebyggelser i Holsten bestod af suburbier i ly af større borganlæg med centralfunktion for den verdslige øvrighed, lokaladelen og den begyndende mission. Den topografiske beliggenhed på et 
fremspringende næs er fælles for 800-tallets Hamborg og 1100-tallets Gamle Lybæk og sandsynligvis for Oldenburg. ${ }^{14}$ Endvidere bør disse steders placering langt fra et sandsynligt konfliktområde eller en grænsezone fremhæves. Bytypen genfindes siden bl.a. i Segeberg (efter 1150), Lauenburg (efter 1200) og muligvis Plön (efter 1160); disse middelalderlige købstæder ligger i grænsezonen mellem det saksiske område i Vestholsten og det indtil 1100-tallet slaviske Østholsten (fig. 8). Derudover kendes kombinationen: borg med suburbium længere østpå, f.eks. ved Stettin i Pommern, hvor den er dateret til omkring $1200 .{ }^{15}$

Over for dette står en anden form for tidlig bymæssig bosætning på den jyske halvø, der blandt andet præges af en fuldstændig mangel på et mindstemål af naturlig beskyttelse. At der enkelte steder på et fremskredet tidspunkt i bysamfundets historie blev anlagt en ofte bueformet vold omkring hele det bebyggede areal, tydeliggør blot den oprindelige sårbare strategiske situation. Det bedst kendte eksempel på denne slags bebyggelse er Hedeby ved Sliens sydlige bred, der er opstået af mindst tre, i perioder samtidige bosætninger ved Haddeby nors vestbred og først i 900-tallet blev koncentreret omkring det mindre bækløb, der forsynede handelspladsen med fersk vand. ${ }^{16}$ Tilsvarende gælder forøvrigt også for Ribe - uden vold - og Århus, der begge er opstået i vikingetid. ${ }^{17}$ Det er $\mathrm{i}$ denne forbindelse ofte blevet overset, at halvkredsvoldene såvel i Hedeby som i Århus tidsfæstes relativt sent til perioden mellem 950 og 1000, altså efter at begge byers eksistens er kendt $\mathrm{i}$ de skriftlige kilder. ${ }^{18}$ Derfor kan det være noget af et definitionsspørgsmål, hvorvidt denne særlige måde at befæste eller afgrænse et byareal på er karakteristisk for yngre vikingetid eller snarere indvarsler tidlig middelalder, som anlægget Brovold på Als kunne tyde på. ${ }^{19}$ Denne plads dateres til anden halvdel af 1100-tallet og tiden efter $1200 \mathrm{og}$ skal efter alt at dømme ses $\mathrm{i}$ forbindelse med en yngre gruppe af bymæssig bosætning beskyttet bag en halvkredsvold, som ikke står til diskussion her. ${ }^{20} \mathrm{Om} 800$-tallets åbne bytype har haft forbilleder sydpå, f.eks. i det nedresaksiske Bardowick ved Lüneborg, der var karolingerrigets nordøstlige forpost, synes vanskeligt at afgøre. Det af en udateret - i dag forsvundet - halvkredsvold afgrænsede byområde på ca. 100 hektars størrelse (Hedeby 24 hektar) ved floden Ilmenau er ikke tilstrækkelig undersøgt af arkæologerne endnu. ${ }^{21}$

For de nævnte lokaliteter fra tiden før år 1000 gælder, at både Hedeby og Ribe ligger i Sønderjylland. Først i midten af det 13. århundrede udskiltes Ribe $\mathrm{i}$ retslig henseende fra det efter 1115 
oprettede jarle- eller hertugdømme Slesvig. Begge byer har tilfælles, at de tidligt var sæde for missionsvirksomhed, der for Ribes vedkommende åbenbart forblev på eller nær den oprindelige plads, ${ }^{22}$ mens det ikke vides, hvorvidt det ældste kirkecentrum ved Slien lå i selve Hedeby og senere, $\mathrm{i}$ forbindelse med omflytningen $\mathrm{i}$ det 11 . århundrede, placeredes i den nuværende købstad, eller om det kan lokaliseres ved middelalderens domkirke. ${ }^{23}$ Hvornår landsdelens tredje bispestad, Haderslev, fik bystatus er ukendt. Det nævnes, at byens grundlæggelse formentlig falder i Valdemar den Stores kongetid. ${ }^{24}$ Udgravninger og topografisk forskning inden for det gamle bycentrum har fortrinsvis været koncentreret i kvarteret omkring det tidligere Haderslevhus og har ikke givet ny viden om byens oprindelse. ${ }^{25} \mathrm{Om}$ "Gammel Haderslev« vest for den senere købstad kan betragtes som forgængerbebyggelse, er svært at afgøre, sålænge hverken nyt skriftligt materiale eller sikre arkæologiske fund giver baggrund for en nyvurdering af spørgsmålet. ${ }^{26}$ Tilsvarende galder forøvrigt for diskussionen omkring problemet, hvorvidt Åbenrå er opstået af fiskerlandsbyen Opnør og (Lille-)Tønder har været afhængig af et ældre Storetønder/Møgeltønder. ${ }^{27}$

Indtil videre kan man derfor gå ud fra, at de ældste bydannelser i det middelalderlige hertugdømme Slesvig lå ved Ribe og Slesvig-Hedeby. Dette understreges af det arkæologiske materiale i regionen (fig. 3). Kun omkring disse to byer er der fremdraget vikingetidsfund i større antal inden for middelalderens byzone eller $i$ umiddelbar tilknytning til denne. For alle andre middelalderkøbstæder i Sønderjylland gælder, at der ikke findes aldre fund i deres nærhed. Dette forhold kan ikke blot verificeres på overregionalt plan, men også belyses ud fra detailkort, f.eks. fra Flensborg og Egernførde. ${ }^{28}$ Konklusionen af denne sammenligning må være den, at der ikke foreligger noget bevis for en bosætningskontinuitet fra vikingetid til middelalder ved byerne $\mathrm{Ha}$ derslev, Åbenrå, Sønderborg, Tønder, Flensborg og Egernførde. Tilsvarende gælder ligeledes for Kiel i Holsten, som det ses af kortet. ${ }^{29}$ I Rendsborg fandtes der for kort tid siden grubehuse fra vikingetid nær den senere bykirke, placeret midt i den ældste købstad. ${ }^{30}$ Bebyggelsens omfang, datering og varighed set i forhold til middelalderbyen er endnu uafklarede spørgsmål, så foreløbig kan byen ikke inddrages i denne del af analysen om de sønderjyske købstæder.

I den seneste tid er det takket være bl.a. arkæologiske undersøgelser lykkedes at få mere viden om Slesvigs og Ribes gamle centre. Når det disse steder har været muligt at supplere det skriftlige kildemateriale på væsentlig måde ved hjælp af jordfund, så skyldes det især de avancerede 


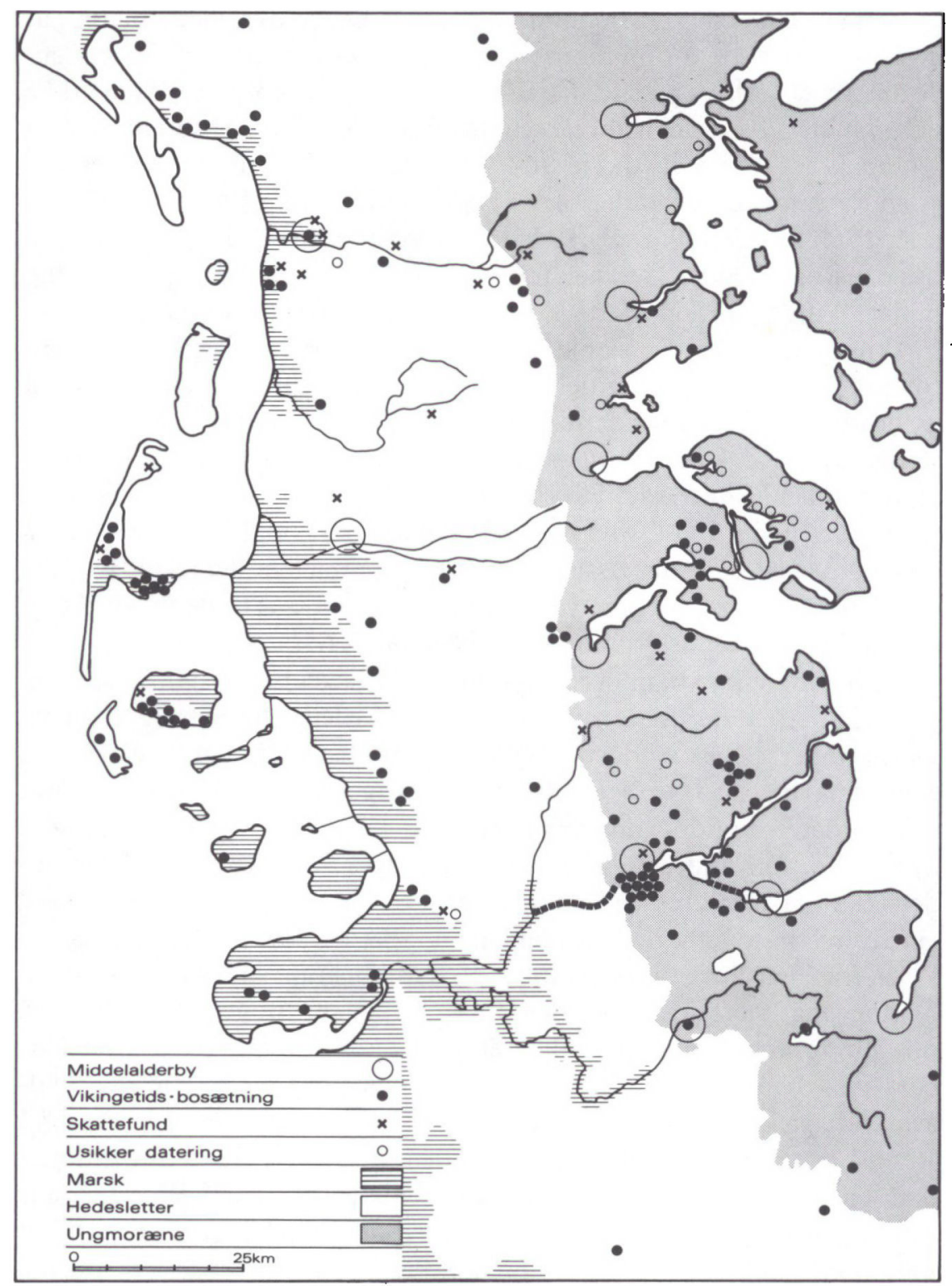

Fig. 3. Vikingetidsfund og middelalderbyer $i$ Sonderjylland. Omtegnet efter $O$. Harck. 
dateringsmetoder, som udvikledes fra naturvidenskabeligt hold i løbet af 70-erne. I Slesvig kunne man f.eks. tidsfæste den første bebyggelse ved havnen nøjagtigt til bestemte år inden for anden halvdel af 1000tallet ved dendrokronologiske målinger på træværk fra den ældste skibsbro. ${ }^{31}$ Spørgsmålet om, hvorvidt disse konstruktioner en skønne dag kan føres tilbage til tiden før 1066, da slaviske krigere ødelagde Hedeby på Sliens sydbred, er dog stadigvæk ubesvaret. Omvendt rejser sig et tilsvarende problem for bebyggelsen ved Haddeby nor, hvor det trods årtiers intensiv forskning ikke har været muligt at påvise en sikker bosætning efter slavernes hærgen. ${ }^{32}$ Den gamle diskussion om Slesvigs betydning som Hedebys arvtager efter 1066 eller som samtidig, muligvis endog konkurrerende samfund er således langtfra afsluttet. ${ }^{33}$

De senere års udgravninger $\mathrm{i}$ Hedeby havn har ganske vist frembragt fund, der muliggør en ny tolkning af hele denne videnskabelige problemstilling. Hidtil ukendte broanlæg fra handelspladsens yngste fase kan tydes som et sidste forsøg fra Hedebys indbyggere på at imødegå en isolering som følge af, at nye skibstyper fik indpas $i$ Østersøen efter år 1000. ${ }^{34}$ Disse fartøjer kunne ikke længere trækkes op på strandbredden om natten $\mathrm{i}$ lighed med vikingernes langskibe og krævede derudover betydelig dybere vand og bedre besejlingsforhold end dem Haddeby nor bød på. ${ }^{35}$ Begge dele fandtes omkring bebyggelsen på Sliens nordbred.

Samtidig med denne udvikling på handelsområdet gennemgik samfundet som helhed en større forandring. Kongemagtens og kirkens fælles fremgang som førende magtfaktorer inden for riget satte varige spor $\mathrm{i}$ byernes undergrund. Lokaliseringen af bygningsrester fra den $\mathrm{i}$ de historiske kilder nævnte kongsgård, af flere kirker og mulige voldrester og gader i Slesvigs første større bebyggelse omkring domkirken står sammen med borganlægget på Mågeøen, der dateres til begyndelsen af det 12 . århundrede, i tydelig kontrast til det arkæologiske materiale fra Hedeby, som ikke kender til bygninger af tilsvarende kvalitet. ${ }^{36}$ Hvorvidt der ud over disse tværvolde nord for domkirken har været palisadehegn eller en jordvold rundt omkring hele det bebyggede område, vides ikke. Der henvises $i$ den forbindelse til de skriftlige kilders oplysning om, at indbyggerne i 1131 formåede at forsvare sig, da kong Niels og sønnen Magnus gik til angreb på Slesvig ved at gå over den tilfrosne Sli. ${ }^{37}$ Af $\mathrm{H}$. Stoobs oversigt, der danner grundlag for fig. 4-5, erkendes, at en voldforskydning i nordlig retning skyldes en udvidelse af byarealet før 1200 . Til de ældste gader hørte 


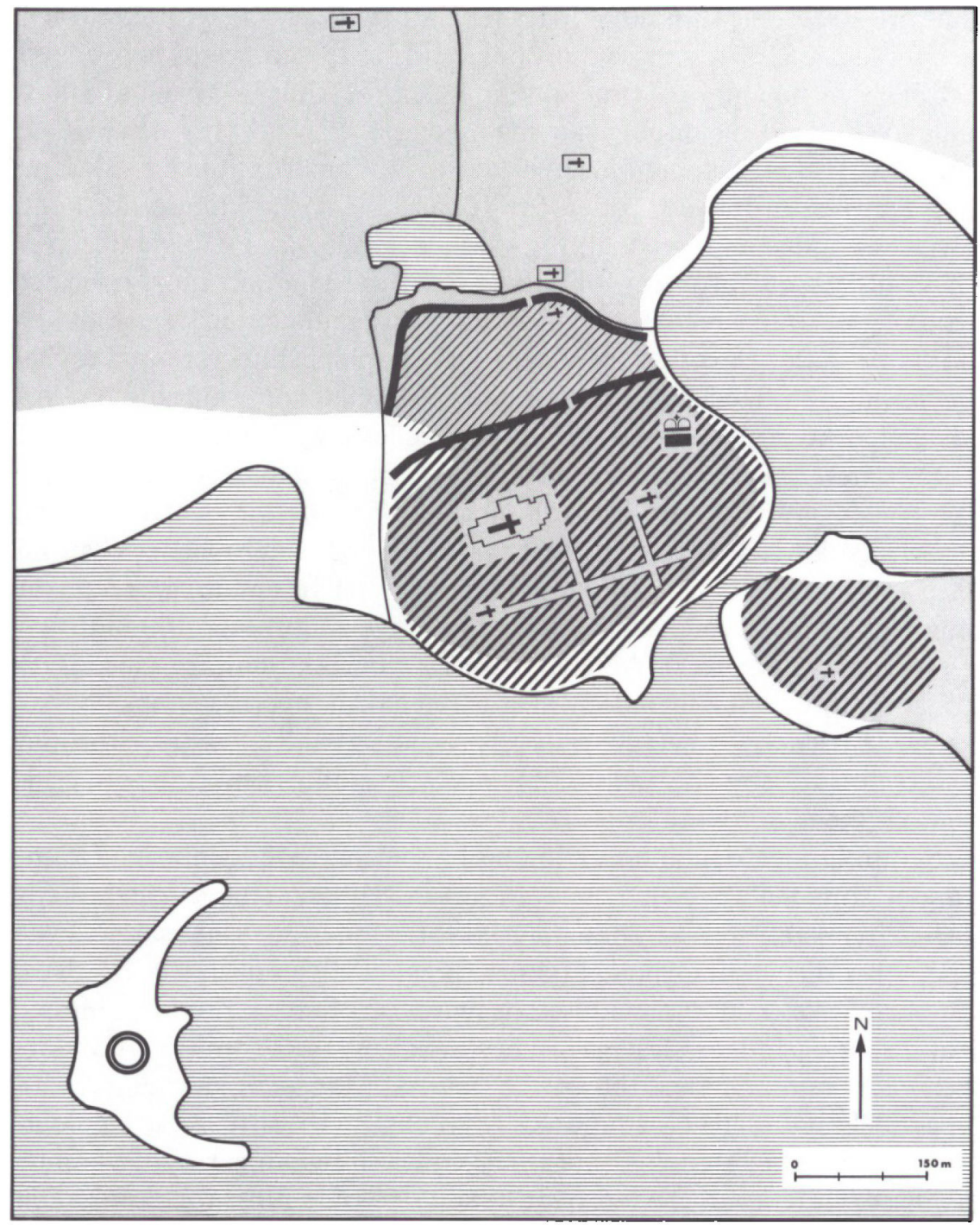

Fig. 4. Slesvigs begyggelse i 1100-tallet. Byens udvikling $i$ to udvidelsesfaser markeret ved voldene. Om disse kun har beskyttet byen mod landsiden eller endog har fort hele vejen rundt er ukendt. Domkirke, andre kirker, kongsgården og gaden Fule Twiete indtegnet. Kysten viser middelalderens strandbred. Mage日en med hertugborg. Grundmorane grdfarvet. Omtegnet efter $\boldsymbol{H}$. Stoob. 


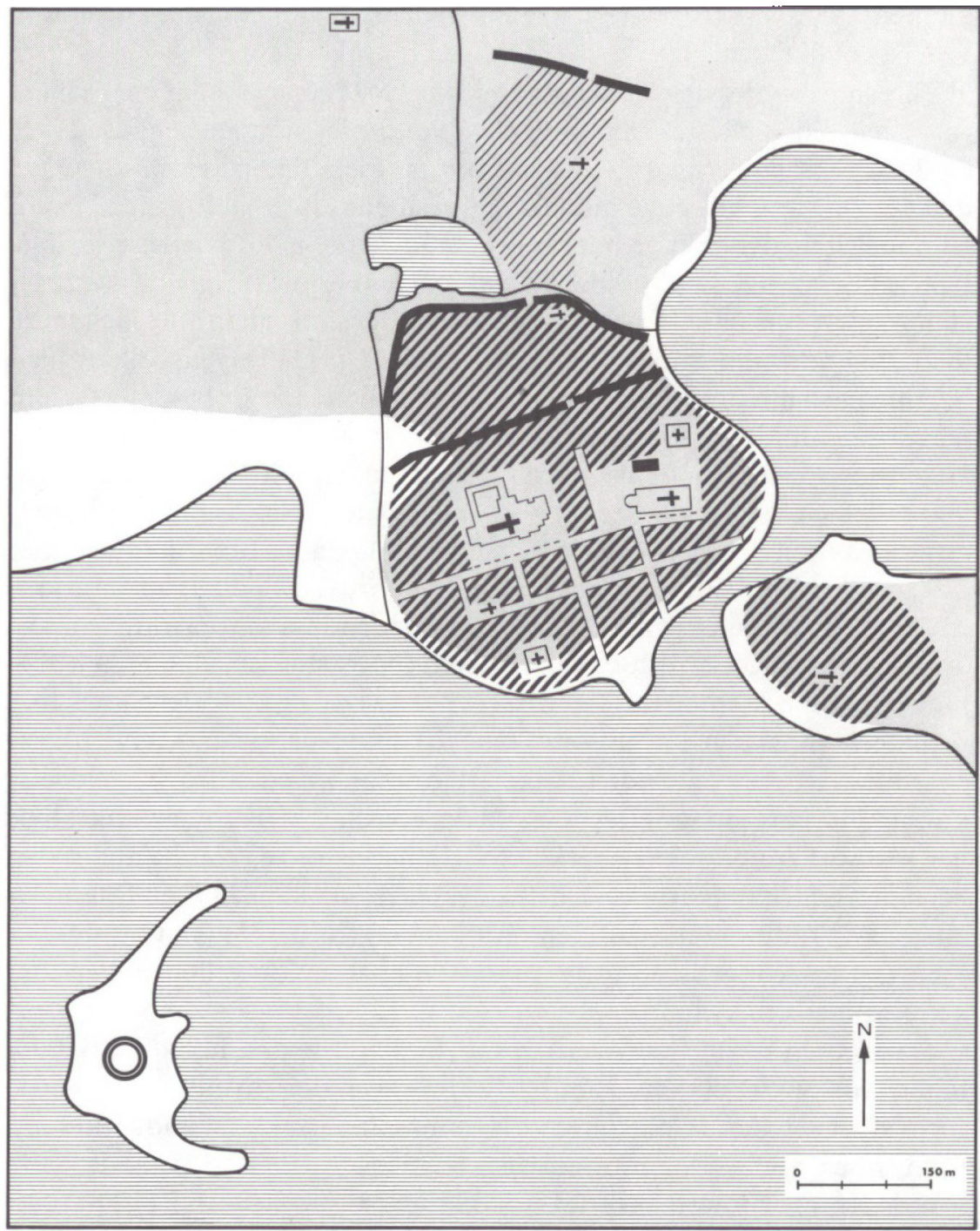

Fig. 5. Slesvigs byplan efter 1200. Planen viser den nordlige udvidelse, kirkerne, klostrene (med lille korssignatur), torvet og torvekirken St. Trinitatis, dertil est-vest-gaden nord for Fule Twiete. Omtegnet efter H. Stoob. 
åbenbart øst-vest-forbindelsen Fule Twiete, der tog sit udgangspunkt ved Nikolaikirken. ${ }^{38}$

Planen over Slesvigs første tid omkring år 1100 viser et af en - senere to - tværvolde befæstet næs omgivet af vand eller sumpede engdrag (fig. 4). Den minder dermed i høj grad om middelalderens Hamborg med den verdslige og kirkelige magthavers residens i hver sit hjørne af byen. Et andet lighedspunkt er borganlægget liggende uden for det egentlige byareal, adskilt ved et bredere vand. ${ }^{39}$ Denne iøjnefaldende overensstemmelse giver anledning til følgende diskussion. Hamborg begyndte med et suburbium omkring et fast borganlæg. Dette genspejler åbenbart et bestemt samfundsmønster, idet en lignende opbygning - som nævnt - genfindes 250 år senere under tilsvarende ydre omstændigheder i Gammel Lybæk, men ikke nord for Ejderen. Her kendtes derimod i 8 900-tallet udelukkende den åbne handelsplads med bymæssig bosætning. Hverken det historiske kildemateriale, de arkæologiske fund eller den topografiske situation f.eks. i Hedeby fortæller om en samfundsopbygning, hvor enkeltpersoner i en fremtrædende magtposition kom til at præge bebyggelsen eftertrykkeligt ved forsvarsanlæg eller enkeltbygninger svarende til dem, vi finder f.eks. i Hamborg. Fællesskabet formåede ganske vist at opføre Danevirkevoldene, og en konge fik sat en runesten over en falden kriger. Dog har ingen gruppe i Hedeby kunnet markere sig for eftertiden ud fra et arkæologisk synspunkt, hvis der ses bort fra en lokal overklasses rigmandsgrave, blandt andet den berømte bådskammergrav syd for Halvkredsvolden. ${ }^{40}$ Der foreligger altså bevis for en social differentiering inden for datidens samfund, der - bortset fra kongens position - sandsynligvis er forskellig fra den, der kendtes længere sydpå.

Da Hedebys funktion overtoges af Slesvig i anden halvdel af 1000tallet, var vikingetidens samfundsmønster $\mathrm{i}$ den ovenfor skitserede form stort set gået $\mathrm{i}$ opløsning. ${ }^{41}$ Nye magtinstitutioner trådte nu også frem nord for Ejderen i europæisk tilsnit. Hermed var de ydre forudsætninger for en ensartet udvikling af bystrukturen i 1100-tallets Hamborg og Slesvig givet. Hertil kom så behovet for etableringen af en selvstændig købmandsstand som et vægtigt aktiv inden for middelalderens samfundstruktur.

Kortet fig. 3 med indtegning af vikingetidsfund og middelalderbyer giver ud over de førnævnte oplysninger om den lokale bebyggelseskontinuitet anledning til at fremsætte følgende tolkning. Middelalderkøbstæderne uden tradition siden vikingetid kunne f.eks. være grundlagt ved magtbud ud fra forudbestemte kriterier. Det er f.eks. 
iøjnefaldende, at disse byer udviser en ensartet topografisk beliggenhed ved eller med adgang til åbent vand, og at de er anlagt på steder uden for det af vikingebønderne opdyrkede område. ${ }^{42}$ Som et vigtig argument for en vis form for planlægning kan der henvises til en retshistorisk baggrund for problemstillingen. Mange gamle byer i Danmark lå på kongens jord, det såkaldte kongelev. ${ }^{43}$ Fra Ribe og Hedeby foreligger der henvisninger til, at landets førstemand i vikingetiden ejede jordarealer, som blev stillet til disposition for det ældste missionsarbejde $i$ eller ved disse to byer. ${ }^{44}$ Kongelevet var $i$ valdemarstiden en del af kongemagtens økonomiske grundlag. Det forklarer, hvorfor optællingen af rigets indtægter i Valdemars jordebog netop omfatter mange af de nye købstæder som skattepligtige over for kongen. ${ }^{45}$ En del af disse jorder bestod i tidlig middelalder af uopdyrkede arealer, alminding, som kongedømmet allerede i Svend Tveskægs dage forsøgte at drage ind under kronens besiddelse. ${ }^{46}$ En diskussion omkring denne fortolkningsmulighed vil blive taget op senere.

Oplysningerne om samtlige sønderjyske byers ældste historie er generelt set få og mangelfulde med hensyn til konkrete informationer om den enkelte bys tilblivelsesproces. Indirekte er det dog lykkedes for historieforskningen at få fremdraget flere aspekter, der kan bruges til belysning af de tidlige købstæders udvikling. Hertil hører f.eks. en analyse af de forste handelslags - gildernes - forhold, som E. Hoffmann for nogen tid siden offentliggjorde som en slags arbejdshypotese. ${ }^{47}$ Den går $\mathrm{i}$ korthed ud på at dele hertugdømmets yngre byer op i to grupper baseret på tilstedeværelsen af henholdsvis knudsgilder fra omkring $1200 \mathrm{og}$ nikolajgilder fra ca. 1250. Til trods for usikkerhed omkring visse byers gildeforhold bidrager E. Hoffmanns undersøgelse med nye synspunkter $i$ den diskussion, denne artikel tager op udfra andre forudsætninger.

Den arkæologiske forskning har med hensyn til de i 12-1300-tallet grundlagte byer ikke givet mange resultater. Fra de nordslesvigske købstæder findes så godt som ingen beretninger om en udgravningsvirksomhed eller om bytopografiske studier inden for middelalderens byzone. ${ }^{48}$ Syd for grænsen foreligger der derimod en fremragende topografisk undersøgelse af det æeldste Flensborg. ${ }^{49}$ Den enestående chance, nedgravningen af et fjernvarmenet kunne have givet for supplerende viden om fjordbyens oprindelse, blev ikke udnyttet til trods for henstilling i den retning. ${ }^{50}$ Kun i Slesvig og Egernførde har saneringsprojekter og opførelsen af nybygninger været under kontrol fra videnskabeligt hold. Førstnævnte sted udgør udgravningsvirksom- 
heden en del af et større forskningsprojekt, der fortrinsvis beskæftiger sig med 1000-tallets og 1100-tallets historie, altså tidsrummet omkring flytningen fra Haddeby nor til Sliens nordbred. ${ }^{51}$ I denne forbindelse har spørgsmålet omkring valdemarstidens samfund og struktur været inddraget $i$ undersøgelserne. Resultaterne foreligger trykt i flere afhandlinger; en planlagt omfattende publikation af materialet kan dog medføre forskydninger og en nyvurdering af 1200 -tallets byhistorie. Af H. Stoobs byplan fremgår ikke bare en betydelig udvidelse af det nordlige bebyggelsesområde $\mathrm{i}$ det 13 . århundrede - set $\mathrm{i}$ forhold til den forudgående periode - men også to nye klostres placering ved havnen og på den ældre kongsgårds ruin (fig. 5). ${ }^{52} \mathrm{~V}$. Vogels udgravninger nord for Rådhuspladsen henviser derudover til et markant skift $\mathrm{i}$ bosætningsstrukturen mellem byens første tid, dateret til det tidlige 12 . århundrede, med en åbenbar planløs bebyggelse uden tilknytning til torvet og et yngre afsnit i 13-1400-tallet, der karakteriseres af en systematisk matrikelinddeling. ${ }^{53}$ Fundet af en tidlig, hidtil ukendt kirke omgivet af en tilhørende gravplads under torvets brolægning i sommeren 1982 har konkretiseret formodningen om en tilbundsgående nyordning af byområdet efter $1200 . .^{54}$ Efter alt at dømme var kirken $i$ brug mellem 1091 og 1205 . V. Vogel tidsfæster på dette grundlag det første torv over kirkeruinen til det 13. århundrede. Samtidig med opførtes Trinitatiskirken ved siden af markedspladsen; den blev nedrevet efter reformationen. ${ }^{55}$ Det formodes, at der i gammel tid lå en gyde mellem torv og havnepladsen mod syd. Denne krydsede den førnæunte øst-vest-forbindelse »Fule Twiete« og dannede muligvis sammen med Hafenstrasse de vigtigste passager til skibsbroen. ${ }^{56}$ Den ny byplan omkring torvet brød med den gamle ordning. Hvorvidt dette også indebar, at "Fule Twiete« $\mathrm{i}$ betydning afløstes af den nordligere beliggende parallelgade (Süder-Dom-Strasse, Töpferstrasse) er svært at bedømme. Denne vejføring ville være uden tilknytning til et gade- eller vejsystem, der strakte sig uden for byens område, men den forbandt byens nye centrum, omfattende markedsplads, torvekirke, rådhus og gildehus, med domkirkekvarteret.

Om Egernførdes oprindelse giver det historiske kildemateriale kun sparsomme oplysninger, idet byens arkiv sandsynligvis gik til grunde ved en brand i 1416 eller $1417 .{ }^{57}$ Lokaliteten på halvøen mellem Østersøen og Vindeby nor nævnes første gang i et holstensk dokument fra 1197 (fig. 6). I 1231 forekommer navnet Egernborg i Valdemars jordebog. Betegnelsen dukker op for sidste gang i 1441, men forinden bruges den i tilknytning til et statholdernavn og er i 1420 dokumenteret 


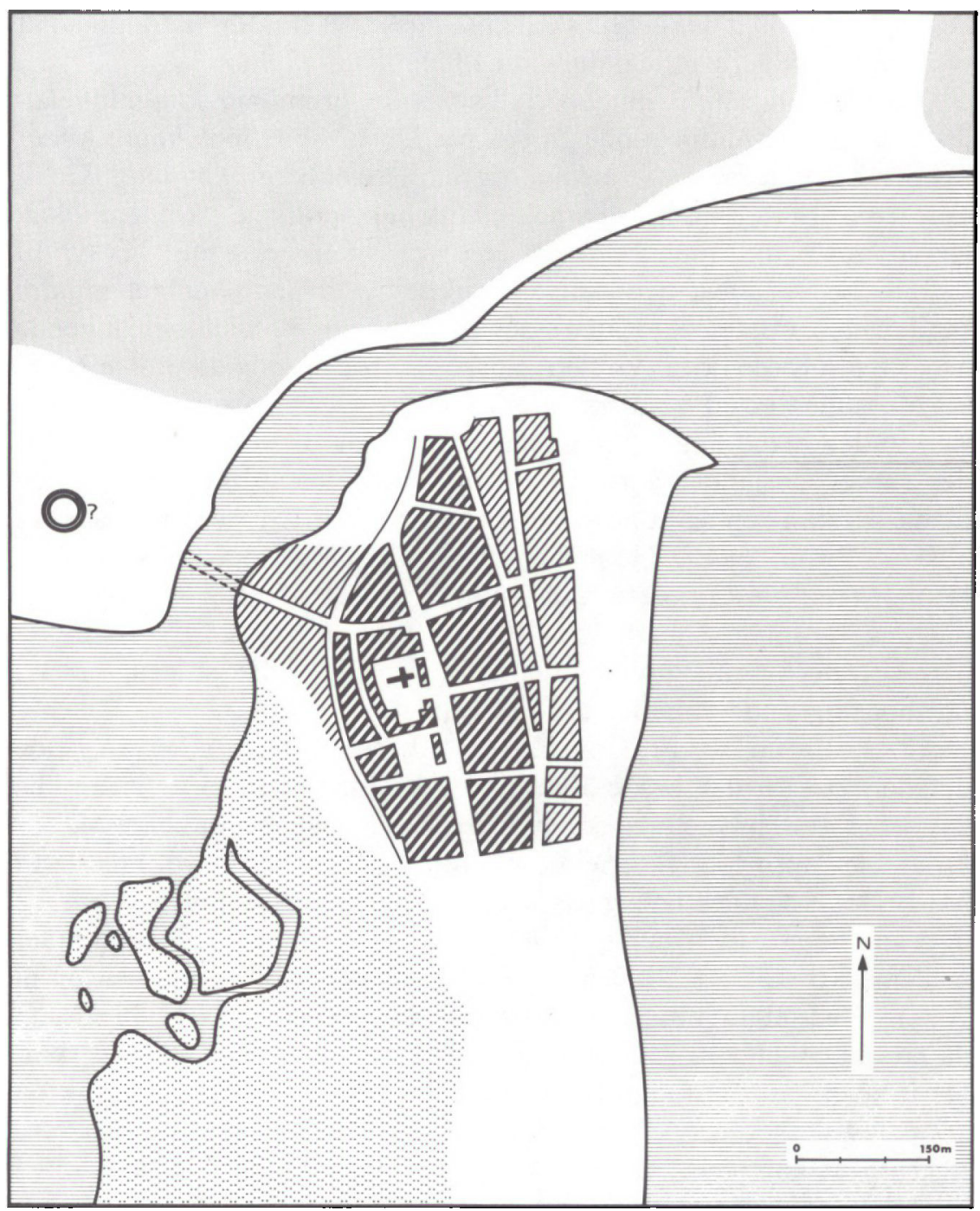

Fig. 6. Egernfordes byudvikling. Ost for den aldste bosatning omkring kirke og torv strandvoldbebyggelsen. Omtegnet efter $O$. Harck.

i forbindelse med borgens genopbygning kort efter byens brand. En kilde i 1288 fremhæver Egernførdes status som retsområde - et "judicio« -, ikke som en bymæssig bebyggelse. Retsformen "købstad" anføres første gang i 1325. 23 år tidligere har staden dog været en 
kendsgerning, idet der $\mathrm{i}$ et lybsk arkiv findes eller fandtes et fragment af et bysegl fra Egernførde dateret til 1302.

Disse få oplysninger udgjorde stort set det grundlag, som middelalderhistorikerne hidtil kunne bygge på. Dertil kom som yngre kilder bykort og billeder i G. Braun og F. Hogenbergs Civitates Orbis Terrarum fra 1584 og C. Danckwerths kartografiske værk fra 1652. Disse viser blandt andet vidtgående overensstemmelse med hensyn til kirkens beliggenhed, gadenettets struktur og broen over det mindre sund mellem Østersøen og den siden istiden nærmest afsnørede inderste del af Egernførde fjord, Vindeby nor. Nord for byen lå der ifølge begge kortdokumenter en vold nær Borby kirke. Denne anses for at have været uden betydning for middelalderens bydannelse. I hvert fald var den sløjfet, da landsbykirken i Borby opførtes omkring 1200 på den plads, der kan tænkes at have været et ældre voldsteds centrum. Stikket hos G. Braun og F. Hogenberg viser derudover jordsoklen til en tårnborg nordvest for det smalle sund. Her drejer det sig sandsynligvis om den fæstning, som navnet Egernborg var knyttet til. Indirekte henviser byens våben til denne tolkning, idet billedet gengiver en tårnborg liggende umiddelbart ved vandet.

Af G. Braun og F. Hogenbergs stik fremgår desuden følgende detaljer: Øst for den brede hovedgade, der før i tiden forte fra en lille byport i syd til havnen i nord, hvor der kan have ligget et færgested før broen blev opført, er gadenettet vifteformet - smallest i syd, breddest i nord. Dette skyldes bebyggelsen af et strandvoldsystem med husene liggende højest, hvor der var tørt, og gaderne lagt i de smalle render mellem hver større sandaflejring. Gadesystemet er bibeholdt helt op til vor tid. Ved udgravninger og kartografiske analyser er det lykkedes at datere de enkelte strandvoldafsnit takket være fund af typiske skår. Derigennem er de topografiske forhold nu sikret både i geologisk og arkæologisk henseende. Hvis man går ud fra, at sandtilførslen til Egernførde-halvøens strand har været nogenlunde konstant siden byens grundlæggelse efter 1200 , er det endog muligt at beregne den middelalderlige strandbreds beliggenhed og derefter at rekonstruere bebyggelsens oprindelige omfang omkring hovedgaden, kirken, der af fagfolk dateres til 1200-tallet, og torvet. Nye udgravninger vest for sidstnævnte sted har givet dokumentation for, at en bebyggelsesudvidelse i den retning var utænkelig på grund af faren for oversvømmelse hver gang vestenstormene piskede Vindeby nor op. Imellem kulturlag fra 13-1400 fandtes tydelige sandaflejringer, der kun kan være opstået som følge af sedimentation under højvande. Den eneste nogenlunde 
sikre bebyggelsesmulighed lå derfor i strandvoldområdet øst for bykernen. Denne "nystad « blev forbundet med hovedgaden ved smalle gyder, anlagt i forbløffende regelmæssig afstand på tværs af strandvoldene, mens gadenettet vest for hovedgaden viser en mere eller mindre bueformet struktur omkring kirke og torv. I forbindelse med brobyggeriet før 1584 anlagdes en senere "nystad « mellem den aldste bebyggelse og broens sydlige ende. Den karakteriseres af en forholdsvis bred gadeudbygning i klar modsætning til de smalle tværgyder $i$ centrum.

I forbindelse med denne tolkning rejstes spørgsmålet, hvorvidt 151600-tallets kort gengiver Egernførdes byplan før branden og dermed dokumenterer middelalderens forhold. I flere snit nord for kirken omkring en af de smalle passager lykkedes det at påvise en pladskontinuitet fra den første bebyggelses dage op til vor tid, hvormed G. Braun og F. Hogenbergs stik vinder som historisk kilde. Et sted kunne der f.eks. måles indtil ti lag af stampet lergulv liggende tæt over hinanden. Det nederste tildakkede planeringsfyld med skår fra ca. 1300, altså fra en periode efter byens grundlæggelse. Materialet viser, at sidegaden nord for kirken ikke hører til byens ældste kvarter, der sandsynligvis $i$ den første tid kun bestod af hovedgaden, kirken og torvet, hvor der ikke har været mulighed for udgravninger endnu.

Egernførdes kirke og den såvel arkæologisk som historisk set udaterede kvadratiske markedsplads er anlagt ved siden af hovedgaden fra syd til nord på den måde, at der kunne opføres bygninger både mellem kirke og torv, kirke og hovedgade, markedsplads og hovedgade. Denne placering af torv og kirke $i$ forhold til hovedfærdselsåren genfindes flere steder i Sønderjylland (fig. 7-8). I Rendsborg fører den gamle hovedvej (Mühlenstrasse-Schleifmühlenstrasse) tværs over Ejderøen. Kirke og torv ligger lidt tilbage i forhold til denne, adskilt ved enkelte bygninger. Mindre gyder (Hohe Strasse og Neue Strasse) forbandt markespladsen med skibsbroen vest for 1200-tallets bebyggelse. Åbenbart lå den ældste borg under den nuværende slotsplads. ${ }^{58}$ Tilsvarende gælder for Flensborg - Nørretorv og Søndertorv. Sidstnævnte sted kunne hovedgaden på grund af terrænforholdene ikke forlænges sydover, men delte sig $\mathrm{i}$ øst-vest-forbindelsen Frisergade og Angelbogade. Fra Nørretorv fører Skibbrogade ned mod havnen. Byens "faste hus« lå efter alt at dømme i Mariegade på "Hjemmets« grund. ${ }^{59}$ Til denne bytype hører endvidere Tønders grundplan. Ved den dominerende øst-vest-gade på tværs af den oprindelige lille holm (Vestergade-Storegade- Østergade) ligger markedspladsen og Nikolajkirken, hvis sene datering til midt i det 14. århundrede overrasker. Dog 

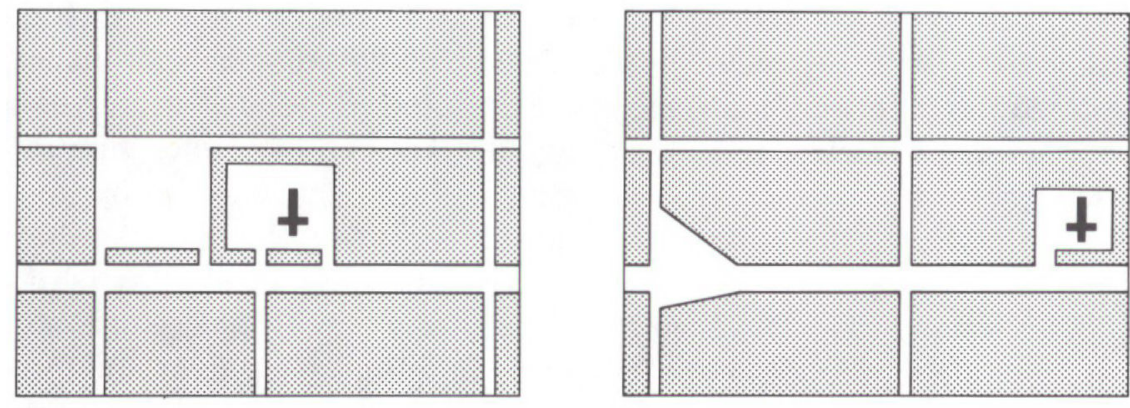

II

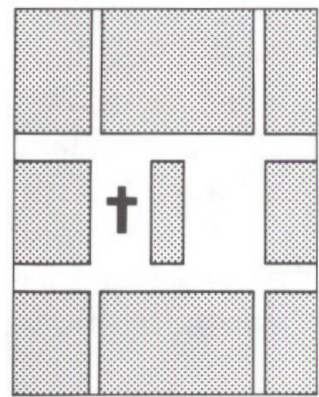

III

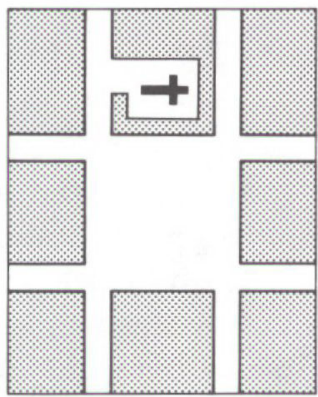

IV

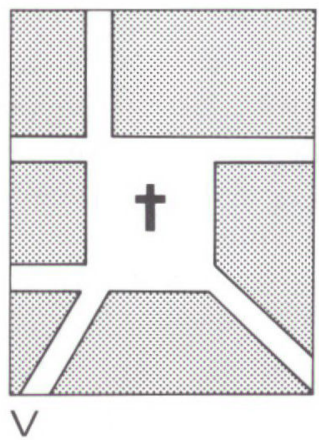

Fig. 7. Oversigt over bytyperne i Slesvig og Holsten.

er det ikke udelukket, at den er opført på en ældre ukendt kirketomt. Fra hovedgaden fører flere gyder til den tidligere skibsbro ved Vidåen. Tønderhus ligger afsides $\mathrm{i}$ forhold til den ældste bymæssige bosætning. ${ }^{60} \mathrm{~V}$. Lorenzen og S. Schoubye beskriver og daterer en gennemgribende regulering af byens grundforhold til tiden omkring 1230 , whvor der tilsyneladende ovenfra dikteres en storstilet byplanlagning, der først finder sit sidestykke i dette århundrede ${ }^{61}$ Det fremgår ikke af sammehængen, hvorpå V. Lorenzen og S. Schoubye bygger denne sikkert rigtige antagelse, der stort set er koncentreret omkring en beskrivelse af den markante grundinddeling i lange smalle "stavne«, der $\mathrm{i}$ lignende form kendes fra andre sønderjyske byer. Den ældste bebyggelse i Tønder har ifølge lokalhistorikernes mening ligget omkring den nedbrudte St. Laurentius-kirke i Vestergade. Hvorvidt dette kan underbygges ved hjælp af arkæologiske fund eller igennem det historiske kildemateriale, er det umuligt at bedømme ud fra de 


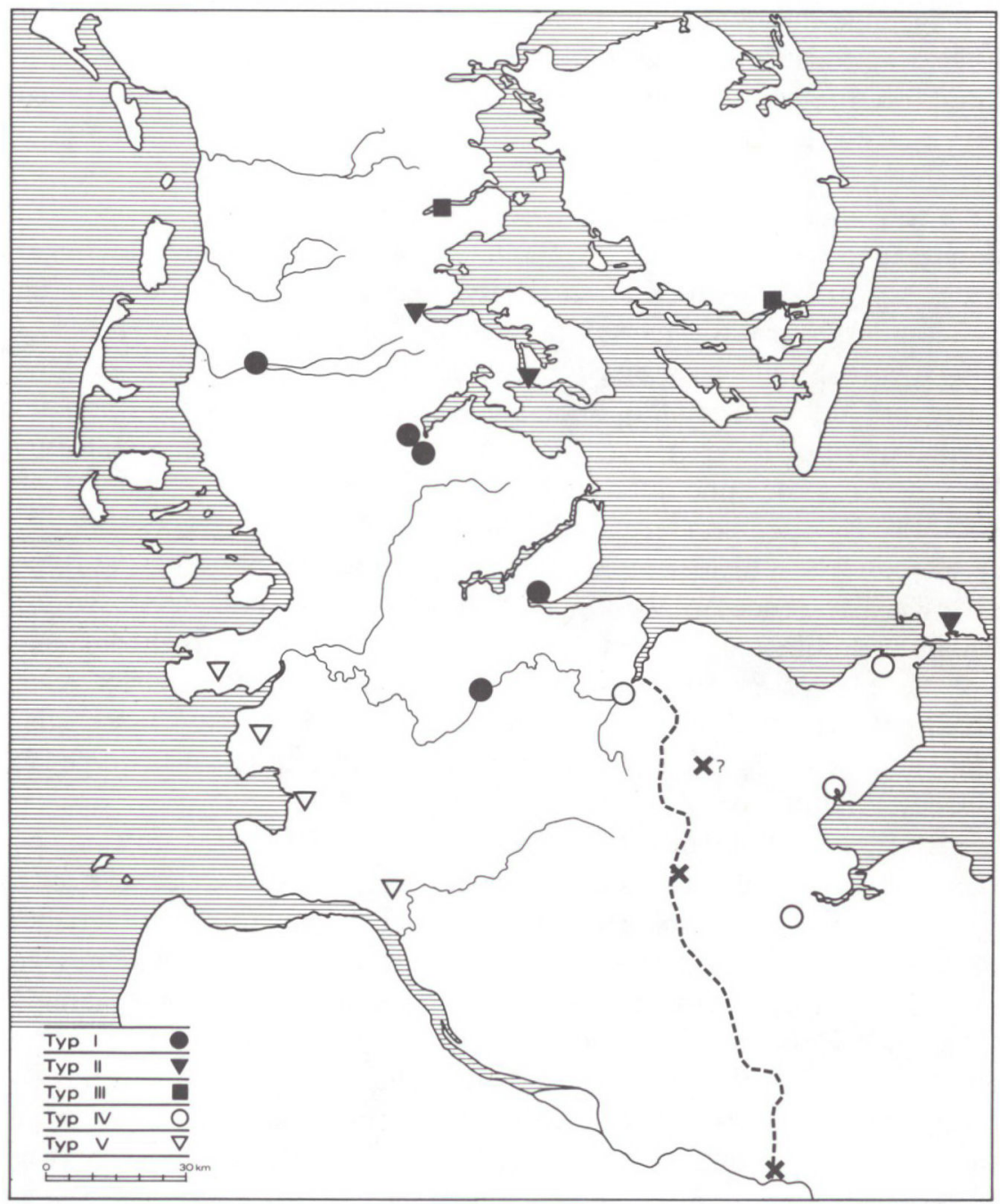

Fig. 8. Fordelingen af bytyperne (fig. 7) mellem Elben og Konged. Slesvig er på grund af usikkerhed omkring 1200-tallets gadeforing ikke medtaget $i$ oversigten. Holstenske kebstoeder fra middelalderen med kombinationen: Borg-suburbium er indtegnet med et $X$. Gransen mellem det slaviske og det saksiske omrdde i Holsten, Limes Saxoniae, indtegnet mellem Kiel og Lauenborg. 
foreliggende publikationer. I forbindelse hermed bør den med forbehold fremførte hypotese som en øst-vest-hovedgade lige syd for domkirken og torvet i Slesvig indføjes, idet et centralt gadesystem med torv og smøger til havnen i denne udformning svarer til den her omtalte byplantype »I«. I kvarteret omkring Slesvigs torv kunne byarkæologerne - som nævnt - påvise en nyordning af matrikelsystemet og dertil datere markedspladsen til efter 1205. Det vil sige, at der foreligger kriterier for en regulering af ældre bebyggelse eller muligvis en systematisk bygrundlæggelse i forskellige sønderjyske byer.

I Åbenrå, Sønderborg og Burg på Femern, der siden valdemarstiden hørte ind under hertugdømmet Slesvig, viser byplanen derimod en afvigende opbygning. Hovedgaden er udvidet til et trekantet torv i bebyggelsens ene ende, mens kirken ligger i den modsatte (type II). ${ }^{62}$ En tredie bytype i Sønderjylland kendes fra Haderslev. Den karakteriseres ved to hovedgader på hver side af såvel torv som domkirke (type III). En tilsvarende opbygning genfindes f.eks. i Svendborg. ${ }^{63}$ Syd for Ejderen dominerer helt andre grundplaner. I flere østholstenske købstæder krydses torvet af to par parallelgader (type IV: Lybæk, Kiel, Neustadt, Heiligenhafen?), hvorimod byer og flækker langs vestkysten kendetegnes af en midt på markedspladsen liggende kirke (type V: Wilster, Meldorf, Wesselburen, Garding?). ${ }^{64}$

Den fremførte opdeling af regionens middelalderlige bysamfund $i$ en slesvigsk bygruppe over for en tilsvarende i det holstenske er selvfølgelig kun et tolkningsforsøg ud fra det lidet, de historiske kilder, det arkæologiske materiale og de topografiske forhold giver af viden. Den iøjnefaldende overensstemmelse mellem de enkelte byers grundplan må tages med forbehold, så længe vi ikke har dokumentation for, at de ældste bykort virkelig genspejler middelalderens struktur. Forudsætningen for en kontrol af teorien om en forudbestemt opdeling af de områder, der i løbet af 1200-tallet blev til levedygtige købstæder, er arkæologiske udgravninger inden for byernes centre. Fremover gælder det derfor om at sikre alle spor af ældre bebyggelse, af den primære matrikelinddeling og det centrale gadenets udformning. Erfaringerne fra Slesvig og Egernførde viser det perspektiv, der netop ligger i byarkæologisk forskning i Sønderjylland.

Både Lybæk, Kiel og Neustadt blev grundlagt ved påbud ovenfra. Fra Neustadt kendes endog enkeltheder om de schauenborgske grevers indsats i selve planlægningsfasen. ${ }^{65}$ Hvis de nord for Ejderen liggende købstæder uden tradition siden vikingetidens dage skulle være opstået med en lignende baggrund, som analysen af byplanerne lægger op til, så 
er det rimeligt at stille spørgsmålet, hvem der i 1200-tallet havde magt til og interesse $\mathrm{i}$ at gennemføre en så grundlæggende strukturforandring i hertugdømmet. I dag er det hverken muligt eller rimeligt at svare herpå. Både det arkæologiske og det historiske materiale er endnu alt for spinkelt til spekulationer i den retning. Hertil kommer endvidere, at forholdet mellem byerne og de i deres nærhed liggende borge mange steder er ukendt med henblik på borgenes status overfor konge, hertug eller kirke og derudover - som arkæologisk kriterium - med hensyn til deres opbygning, datering og samtidighed overfor »civilbebyggelsen«. Topografisk set kendes forskellige borgplaceringer. De giver dog intet grundlag for en opdeling i geografisk eller historisk henseende. Voldsteder liggende på en $\varnothing$ uden for byen eller adskilt fra denne ved et sund eller et vandløb kendes f.eks. fra Sønderborg, Slesvig og Egernførde og derudover fra byer uden for Sønderjylland. Borgpladser ved middelalderbebyggelsens grænse eller $i$ den nære bymark er overleveret fra blandt andet Burg, Rendsborg, Flensborg, Åbenrå og Haderslev, fra Holsten og fra Nørrejylland.

Til trods for adskillige forbehold med hensyn til tolkningen af det arkæologiske og topografiske materiale og en del usikkerhed på grund af den forholdsvis mangelfulde historiske viden, som denne undersøgelse bygger på, bør det afsluttende forsøges at tegne en skitse af middelalderens byudvikling. Den ældste bytype nord for Elben bestående af en borg med suburbium findes ikke i Sønderjylland, men derimod i det holstenske (Hamborg, Gammel Lybæk, Oldenburg? Segeberg, Lauenburg og Plön?). Nord for Ejderen dominerer som første bymæssige samfund åbne bopladser (Hedeby og Ribe). Halvkredsvolden ved Haddeby nor, der dateres til slutningen af 900-tallet, kan være en forløber for en typisk måde at befæste middelalderbyer på, idet tilsvarende befæstninger findes ved senere bydannelser (Brovold, Horsens, Viborg, Ålborg, København). Af middelalderkøbstæderne med kontinuerlig bebyggelse siden vikingetid kendes kun Ribe og Slesvig, såfremt denne by opfattes som Hedebys efterfølger. Hvorvidt noget tilsvarende gælder for Rendsborg er ukendt. Omkring de andre middelalderbyer i Sønderjylland, der opstod omkring og efter 1200, Haderslev, Åbenrå, Sønderborg, Tønder, Flensborg og Egernførde foreligger der ingen spor af vikingetidsbosætning i umiddelbar nærhed. Dette kan tolkes som en bevidst bygrundlæggelse ved magtbud på rigets jord uden for tidligere opdyrkede områder. Denne antagelse understreges af bemærkelsesværdig overensstemmelse i topografisk henseende og byplanens udforming, der står i kontrast til byerne i Øst- 
og Vestholsten. Denne antagelse underbygges af arkæologiske fund omkring torvet i Slesvig, der sandsynliggør en gennemgribende nyordning af matrikelsystemet efter 1200 , altså i hertugdømmets egentlige bygrundlæggelsesfase. Spørgsmålet om den politiske hensigt med og den økonomiske baggrund for disse nye bysamfunds oprettelse i 1200 tallet er foreløbig ukendt i enkeltheder. Situationen i Nordeuropa var i denne periode moden til en omstrukturering af samfundet dels som følge af udfordringen fra byerne langs den tyske Østersøkyst, dels på grund af kongemagtens etablering som den sikkerhedsgarant, der var forudsætning for et handelsøkonomisk opsving i datidens Danmark.

\section{NOTER}

1. Artiklen bygger på et foredrag holdt i Odense, Ålborg, Sønderborg, Tønder, Haderslev, Slesvig og Egernførde.

2. Vita Anskarii cap. 12; cap. 16.

3. R. Schindler: Ausgrabungen in Alt Hamburg. Hamburg 1957, $103 \mathrm{ff}$.; H. Thomsen: Hamburg. Handbuch der historischen Stätten Deutschlands 1, Stuttgart 1964, 83 ff.

4. G. Köhler: Civitas und vicus, burg, stat, dorf und wik. H. Jankuhn, W. Schlesinger, H. Steuer (udg.): Vor- und Frühformen der europäischen Stadt im Mittelalter 1, Göttingen 1973, $61 \mathrm{ff}$.

5. H. Koch: Kongemagt og kirke. Politikens Danmarkshistorie 3, 1969, 28.

6. F. Rörig: Die europäische Stadt im Mittelalter. Göttingen 1955, $5 \mathrm{ff}$.

7. Beretningerne findes $i$ ovennæunte bog af $R$. Schindler (note 3), i tidsskriftet Hammaburg 1-7, 1948-61 og i: R. Schindler: Die Bodenaltertümer der Freien und Hansestadt Hamburg. Hamborg 1960.

8. R. Schindler, anf. sted (note 3) $112 \mathrm{ff}$.

9. D. Bohnsack: Der Bischofsturm im Hamburger Stadtkern. Führer zu vor- und frühgeschichtlichen Denkmälern 7, Mainz 1967, 94 ff.; R. Schindler, anf. sted (note 3) $163 \mathrm{ff}$.

10. W. Neugebauer: Der Burgwall Alt-Lübeck. Offa 21/22, 1964/65, $127 \mathrm{ff}$; H. Andersen: Det bjerg, der kaldes Gamle Lybæk. Skalk 1979, h. 2, 9 ff.; G. Fehring: Alt Lübeck und Lübeck. Zur Topographie und Besiedlung zweier Seehandelszentren im Wandel vom 12. zum 13. Jahrhundert. Die Heimat 89, 1982, $181 \mathrm{ff}$.

11. F. eks. Stellerburg ved Heide i Ditmarsken (H. Jankuhn: Die Frühgeschichte. Geschichte Schleswig-Holsteins 3, Neumünster 1957, 67 ff.), Kaaksburg i Ditmarsken (K. W. Struve: Probleme der Burgenforschung im frühgeschichtlichen Holstengau. Urkirchspiel im Holstengau. Hademarschen 1965, 18, Abb. 2.

12. K. W. Struve: Die Burgen in Schleswig-Holstein 1. Neumünster 1981.

13. K. W. Struve, anf. sted (note 12) $37 \mathrm{ff}$.

14. K. W. Struve, anf. sted (note 12) 37, Abb. 2.

15. J. Habich: Stadtkernatlas Schleswig-Holstein. Neumünster 1976, 16 ff.; 88 ff.; 136 ff.; L. Leciejewicz: Die Entstehung der Stadt Szczecin im Rahmen der frühen Stadtentwicklung an der südlichen Ostseeküste. H. Jankuhn, W. Schlesinger, H. Steuer 
(udg.): Vor- und Frühformen der europäischen Stadt im Mittelalter 2, Göttingen 1973, 209 ff., Abb. 5.

16. H. Jankuhn: Haithabu, ein Handelsplatz der Wikingerzeit ${ }^{\circ}$. Neumünster 1976, Abb. $25 ; 26 ; 28$.

17. M. Bencard: Ribes aldste udvikling. Mark og montre 1971, $20 \mathrm{ff}$; M. Bencard: Jagten på Ribe. Skalk 1974, h. 2, 7 ff.; M. Bencard: Ribe zur Zeit der Wikinger. Acta Visbyensia V, 1974, 165 ff.; M. Bencard (udg.): Ribe Excavations 1970-76, 1, Esbjerg 1981; S. Jensen, P. Madsen, O. Schjörring: Udgravninger i Ribe 1979-1981. Mark og montre 1982, 50 ff.; H. Andersen, P. Crabb, H. Madsen: Århus Søndervold, en byarkæologisk undersøgelse. 1971.

18. H. Andersen, H. Madsen, O. Voss: Danevirke. 1976, 68 ff.; H. Andersen, P. Crabb, H. Madsen, anf. sted (note 17) $267 \mathrm{ff}$.

19. J. Kock: Brovold. En befæstet bebyggelse fra tidlig middelalder. Kuml 1978, $193 \mathrm{ff}$.

20. F.eks.: Viborg: H. Krongaard Kristensen, J. Vellev: En ikke ringe ære for byen. Skalk 1982, h. 5,3 ff.; Ålborg: J. Kock: Den enbenede mand. Skalk 1971, h. 4, 18 ff.; J. Kock: Byarkæologisk topografi i Aalborg. Hikuin 2, 1975, 187 ff. Stege: S. Nielsen: Stegeborg. Skalk 1980, h. 4, 3 ff.; København: H. Andersen: Havn. Skalk 1967, h. 1.; Horsens: C. Andreasen, T. Lassen, O. Schjörring: Horsens - en middelalderbys udvikling. Hikuin 3, 1977, $41 \mathrm{ff}$., fig. 5.

21. W. Hübener: Eine topographisch - archäologische Studie zu Bardowick, Kr. Lüneburg. Studien zur Sachsenforschung 4, 1982, $111 \mathrm{ff}$.

22. Se note 17.

23. H. Stoob: Zur Topographie von Alt-Schleswig. Acta Visbyensia V, 1974, $117 \mathrm{ff}$.

24. Sammenfattende: E. Hoffmann: Beiträge zur Geschichte der Stadt Schleswig. Zeitschrift der Gesellschaft für Schleswig-holsteinische Geschichte 105, 1980, $53 \mathrm{ff}$. H. Matthiessen: Haderslev og Aabenraa. København/Flensborg 1925.

25. H. Neumann: Pottemagerovn under Jomfrugang i Haderslev. Haderslev amts museum, 1949, 16 ff.; H. Neumann: Højgade. Haderslev amts museum 4, 1953, 23 ff.; J. Hertz: Apotekergade 11, Haderslev. Haderslev amts museum 9, 1961, 13 ff;; H. Neumann: Hvor lå Hansborg slot? Haderslev amts museum 13, 1968, 35 ff.; H. Fangel: Det middelalderlige Haderslevhus. Nordslesvigske museer 4, 1977, $51 \mathrm{ff}$; $\mathrm{H}$. Fangel: Grevens gård i Haderslev. Nordslesvigske museer 6, 1979, 122 ff.; S. Wulff Andersen, F. Rieck: Et hjørne af Hansborg slot. Nordslesvigske museer 7, 1980, 60 ff.

26. E. Hoffmann, anf. sted (note 24) 54 .

27. H. Matthiessen, anf. sted (note 24) 52; J. Hvidtfeldt i J. P. Trap: Danmark 10, 3, 1967, 846 ff.; V. Lorenzen, Oprindelse - Beliggenhed og Byplan. M. Mackeprang (red.): Tønder gennem Tiderne, Tønder 1943, 34.

28. J. Röschmann: Vorgeschichte des Kreises Flensburg. Neumünster 1963, 79, Abb. 20; O. Harck: Egernfordes oprindelse. H. Jørgensen, O. Olesen, F. Thygesen (red.), Egernførde bys historie. Flensborg 1980, 9 ff., fig. 4; O. Harck: Stadtkernforschung in Eckernförde - Ein Beitrag zur Diskussion der Entstehung früher Städte in Schleswig und Holstein. Offa 37, 1980, 232 ff., Abb. 3.

29. H. Hinz: Archäologische Beobachtungen in der Altstadt von Kiel. Kiel-Papers 72, Kiel 1972, $100 \mathrm{ff}$.

30. Offa 38, 1981, 472.

31. V. Vogel, Die Anfänge des Schleswiger Hafens. Beiträge zur Schleswiger Stadtgeschichte 22, 1977, $21 \mathrm{ff}$. 
32. Meddelt af dr. K. Schietzel, Slesvig.

33. H. Schledermann: Slesvig/Hedebys tilblivelse. Sønderjyske Årbøger 1966, 16.

34. K. Schietzel, O. Crumlin-Pedersen: Havnen i Hedeby. Skalk 1980, h. 3, 4 ff.

35. D. Ellmers: Frühmittelalterliche Handelschiffahrt in Mittel- und Nordeuropa. Neumünster 1972; D. Ellmers: Schiffahrt. Führer zu vor- und frühgeschichtlichen Denkmälern 9, Mainz 1968, $85 \mathrm{ff}$.

36. Kongsgården: C. Radtke: Aula und castellum. Beiträge zur Schleswiger Stadtgeschichte 22, 1977, 29 ff.; D. Lafrenz; Das Graukloster in Schleswig. Baudenkmale in Gefahr 6, Kiel 1982. Kirker: H. Stoob, anf. sted. (note 23); V. Vogel, Die Ausgrabung der Nikolaikirche in Schleswig. Offa 28, 1971, 181 ff.; C. Radtke: Historische Untersuchung zur Schleswiger Nikolaikirche. Beiträge zur Schleswiger Stadtgeschichte 20, 1975, 42 ff.; G. Mettjes: Rekonstruktion und bauhistorische Stellung der Nikolaikirche zu Schleswig. Beiträge zur Schleswiger Stadtgeschichte 20, 1975, 64 ff.; J. Vellev: Die Ausgrabung der Rundkirche "St. Michaelis« in Schleswig. Beiträge zur Schleswiger Stadtgeschichte 18, 1973. Volde og gader: C. Radtke: Aula und castellum, anf. sted 36, Abb. 1; C. Radtke: Historische Untersuchungen, anf. sted. 46 ff., Abb. 1; H. Stoob, anf. sted. (note 23).

37. H. Stoob, anf. sted (note 23) 124 med litteratur; J. Habich, anf. sted (note 15), 104.

38. H. Stoob, anf. sted (note 23), Abb. 3; C. Radtke: Historische Untersuchungen, anf. sted (note 36) $46 \mathrm{ff}$.

39. V. La Cour: Vagttårne ved Slien. Sønderjysk Månedsskrift 47, 1971, $41 \mathrm{ff}$.

40. M. Müller-Wille: Das Bootskammergrab von Haithabu. Berichte über die Ausgrabungen in Haithabu 8, Neumünster 1976.

41. H. Koch, anf. sted (note 5) $11 \mathrm{ff}$.

42. O. Harck, Stadtkernforschung, anf. sted (note 28), 248.

43. P. Jørgensen: Dansk retshistorie. 1940, 422; A. Christensen: Über die Entwicklung der dänischen Städte von der Wikingerzeit bis zum 13. Jahrhundert. Acta Visbyensia I, 1963, $166 \mathrm{ff}$.

44. H. Andersen, P. Crabb, H. Madsen, anf. sted (note 17) 270.

45. P. Jørgensen, anf. sted (note 43) 264.

46. P. Jørgensen, anf. sted (note 43) 186.

47. E. Hoffmann, anf. sted (note 24).

48. Tønder: V. Lorenzen, anf. sted (note 27); L. Andresen: Geschichte der Stadt Tondern. Flensborg 1939, 74 ff.; S. Schoubye: Huse og gader i det gamle Tønder. Nordslesvigske museer 7, 1980, 113 ff. Sønderborg: J. Slettebo: Om det ældste Sønderborg. Nordslesvigske museer 5, 1978, $31 \mathrm{ff}$.; Haderslev: se note 25 .

49. J. Röschmann, anf. sted. (note 28) 93 ff.; V. La Cour: Flensborg og Flensborghus. Sønderjysk Månedsskrift 46, 1970, $71 \mathrm{ff}$.

50. O. Harck: Bykærnearkæologien supplerer historikernes forskning. Flensborg Avis 3. august 1974.

51. V. Vogel: De archäologischen Ausgrabungen im Stadtkern von Schleswig. Ausgrabungen in Deutschland 3, Mainz 1975, $72 \mathrm{ff}$.

52. Litteratur: noterne 23, 31, 36 og 37.

53. V. Vogel, anf. sted. (note 51) $77 \mathrm{ff}$.

54. V. Vogel: Archäologische Stadtkernforschung in Schleswig 1969-1982. Ausgrabungen in Schleswig. Berichte und Studien 1. Neumünster 1983 (i trykning) V. Vogel takkes for indblik i manuskriptet.

55. J. Habich, anf. sted (note 15) 163. 
56. C. Radtke, Historische Untersuchungen, anf. sted (note 36) 47, Abb. 1 .

57. Det følgende bygger på $O$. Harck: Egernførdes oprindelse og Stadtkernforschung, anf. sted (note 28).

58. O. Klose, L. Martius: Ortsansichten und Stadtpläne der Herzogtümer Schleswig, Holstein und Lauenburg, Bildband, Neumünster 1962, 341 ff.; J. Habich, anf. sted (note 15) $152 \mathrm{ff}$.

59. J. Röschmann, anf. sted (note 28); O. Klose, L. Martius, anf. sted (note 58), 47 ff.; J. Habich, anf. sted (note 15) $38 \mathrm{ff}$.

60. S. Schoubye, anf. sted (note 48); O. Klose, L. Martius, anf. sted (note 58) $146 \mathrm{ff}$.

61. S. Schoubye, anf. sted (note 48) 114; V. Lorenzen, anf. sted (note 27) 36.

62. O. Klose, L. Martius, anf. sted (note 58), $19 \mathrm{ff}$; $35 \mathrm{ff}$; $127 \mathrm{ff}$.; J. Habich, anf. sted (note 15) $24 \mathrm{ff}$; J. Slettebo, anf. sted (note 48); O. Harck, anf. sted (note 28) $248 \mathrm{ff}$.

63. H. Reinholdt: Fisketorvet i Svendborg - en identifikation. Hikuin 7, 1981, 37 ff.

64. O. Harck, Stadtkernforschung, anf. sted (note 28) $248 \mathrm{ff}$.

65. J. Habich, anf. sted (note 15) 128. 
